\title{
Fan-like sediments on outer Haltenbanken, mid-Norwegian shelf
}

\author{
J. A. DOWDESWELL ${ }^{1}$, D. OTTESEN ${ }^{2}$, L. RISE ${ }^{2} \&$ C. F. FORSBERG ${ }^{3}$ \\ ${ }^{1}$ Scott Polar Research Institute, University of Cambridge, Cambridge CB2 1ER, UK \\ ${ }^{2}$ Geological Survey of Norway, Postboks 6315 Sluppen, N-7491 Trondheim, Norway \\ ${ }^{3}$ Norwegian Geotechnical Institute, Postboks 3930, Ullevål Stadion, N-0806 Oslo, Norway
}

*Corresponding author (e-mail: jd16@cam.ac.uk)

Subaqueous fans, formed in marine and lacustrine settings, have been reported from both Quaternary and more ancient glacier-influenced environments (e.g. Powell 1990; Dowdeswell et al. 2015). Their presence is often taken to imply a palaeo-glacial environment abundant in sediment-rich meltwater, whose load was sourced from glacial erosion and transported in subglacial channels to the ice margin. The sedimentology of these fans sometimes exhibits bedforms indicative of high-energy water-flow (e.g. Winsemann et al. 2009), suggesting that sudden drainage events may be important in the formation of some glacier-influenced submarine fans.

\section{Description}

A fan-like sedimentary depocentre occurs on the mid-Norwegian shelf on outer Haltenbanken, about $30 \mathrm{~km}$ east of the shelf edge at approximately $300 \mathrm{~m}$ water depth (Fig. 1a, d). It has an oval or lobe-shaped form and a relatively smooth surface where it is undisturbed by subsequent reworking. The feature's longest axis trends WSW-ENE and has a maximum length of $14 \mathrm{~km}$ and a maximum width of $7 \mathrm{~km}$, covering an area of about $70 \mathrm{~km}^{2}$. From bathymetric profiles across the fan, indicating its elevation above the level of the surrounding seafloor (profiles $\mathrm{x}-\mathrm{x}^{\prime}$ and $\mathrm{y}-\mathrm{y}^{\prime}$ in Fig. 1e), a maximum thickness of $30 \mathrm{~m}$ and a volume of 1 to $2 \mathrm{~km}^{3}$ of sediment is inferred, indicating that the fan-like feature makes up a large local depocentre.

Beyond the fan-like deposit, a series of small ridges with a generally NNW-SSE direction is found (Fig. 1a, c); ridge orientations are approximately transverse to the inferred direction of ice flow when ice covered Haltenbanken at the Last Glacial Maximum. The average height of the ridges is about $5 \mathrm{~m}$ and the mean spacing is approximately $200 \mathrm{~m}$. The fan-like depocentre clearly blankets and overprints the sets of ridges (Fig. 1a, d), making it the younger of these two depositional landforms.

Superimposed on both the transverse ridges and the fan-like deposit, reworking its formerly smooth surface, is a series of irregularly distributed narrow depressions, some with lateral berms (Fig. 1a). The predominant orientation of these linear depressions is NE-SW, although a sub-set on the east side of the fan-like deposit has a more southerly component (Fig. 1c). In addition, close to the fan toe, some depressions have a more chaotic appearance and cross-cut the more linear depressions (Fig. 1a, c). The depressions are the youngest morphological features in the area, with the chaotic depressions the youngest among the depressions themselves. To the north-east of the apex of the fan-like depocentre, there are four arcuate escarpments of between 10 and $30 \mathrm{~m}$ in height and $15 \mathrm{~km}$ in length, with two longer but similarly shaped features further to the north (Fig. 1d, e).

\section{Interpretation}

The oval-shaped sedimentary depocentre is interpreted as a submarine fan due to its overall geometry and clear apex, its blanketing of the small transverse ridges, its relatively smooth appearance (where undisturbed), and its relatively small thickness (estimated maximum of about $30 \mathrm{~m}$ ). The depocentre is probably an ice-proximal fan produced by meltwater deposition. Geotechnical measurements acquired during borehole drilling near the fan apex show that up to $5 \mathrm{~m}$ of soft material $(<50 \mathrm{kPa})$ is underlain by much stiffer debris $(>150 \mathrm{kPa})$ (Forsberg \& Pederstad 2009); the former is interpreted as debris forming the depocentre by water delivery from point source(s), probably overlying stiffer diamictic sediment linked to ice loading during the Late Weichelian glaciation. Thinning of the fan towards its apex may be explained by retreat of the ice front and subglacial channel mouth during deposition. The ridges blanketed by the depocentre are interpreted as small retreat moraines formed at a grounded tidewater-influenced ice margin as it retreated across the shelf towards the Norwegian coast from a full-glacial position (e.g. Todd et al. 2007). Morphologically, the four arcuate scarps north-east of the fan (Fig. 1d, e) appear similar to rotational slide blocks imaged on the huge Storegga Slide on the continental slope to the south (Haflidason et al. 2005), although their relatively high shear strength indicates they may be moraine ridges (Forsberg \& Pederstad 2009).

Evidence for meltwater activity is relatively sparse on the mid-Norwegian shelf; there are few submarine landforms characteristic of channelised water flow and there is little evidence of major meltwater deposition (e.g. Ottesen et al. 2005). The source of the sediment-rich water inferred to have produced the fan may have been due to an outburst flood linked perhaps to the drainage of an ice-dammed lake when the ice margin was close by, or to earthquake activity (Olesen et al. 2004), or to failure processes that may have produced the escarpments immediately to the north-east of the fan apex (Fig. 1d). Either of the latter two mechanisms may have led to opening of new drainage pathways, leading to high-magnitude water release.

The depressions on the fan surface are interpreted as the ploughmarks of iceberg keels. The more linear sets of ploughmarks were probably produced at or close to the time of fan formation, when turbid water was released, probably rapidly, to form the depocentre and to transport icebergs directly away from the palaeo-ice margin. Once the flood was over, icebergs would have been free to drift along typically more irregular tracks, forming the more chaotic pattern of ploughmarks that represents the youngest landform on the fan surface (Fig. 1a, c). The dimensions, geometry and thickness of the fan on Haltenbanken are similar to those reported from, for example, subaqueous fans produced by flood events at the southern margin of a mid-Pleistocene Eurasian Ice Sheet (Winsemann et al. 2009).

\section{References}

DOWDESWELL, J. A., HOGAN, K. A., ET AL. 2015. Sediment-rich meltwater plumes and ice-proximal fans at the margins of modern and ancient tidewater glaciers: Observations and modelling. Sedimentology, 62, 1665-1692.

FORSBERG, C. F. \& PEDERSTAD, H. P. 2009. Geotechnical design basis for rig anchoring at Åsgard field. The morphology of the Haltenbanken area Geotechnical implications. NGI Report, 20081217-1,123 pp.

HAFLIDASON, H., LIEN, R., SEJRUP, H. P., FORSBERG, C. F. \& BRYN, P. 2005. The dating and morphometry of the Storegga Slide. Marine and Petroleum Geology, 22, 123-136.

OLESEN, O, BLIKRA L. H., ET AL. 2004. Neotectonic deformation in Norway and its implications: a review. Norwegian Journal of Geology, 84, 3-34.

OTTESEN, D., DOWDESWELL, J. A. \& RISE, L. 2005. Submarine landforms and the reconstruction of fast-flowing ice streams within a large Quaternary ice sheet: The 2500-km-long Norwegian-Svalbard margin $\left(57^{\circ}-80^{\circ} \mathrm{N}\right)$. Geological Society of America Bulletin, 117, 1033-1050. 
POWELL, R. D. 1990. Glacimarine processes at grounding-line fans and their growth to ice-contact deltas. In: Dowdeswell, J. A. \& Scourse, J. D. (eds) Glacimarine Environments: Processes and Sediments, Geological Society, London Special Publications, 53, 53-73.

TODD, B. J., VALENTINE, P. C., LONGVA, O. \& SHAW, J. 2007. Glacial landforms on German Bank, Scotian Shelf: evidence for Late Wisconsinan icesheet dynamics and implications for the formation of De Geer moraines. Boreas, 36, 148-169.

WINSEMANN, J., HORNUNG, J. J., ET AL. 2009. Anatomy of a subaqueous ice-contact fan and delta complex, Middle-Pleistocene, North-west Germany. Sedimentology, 56, 1041-1076.
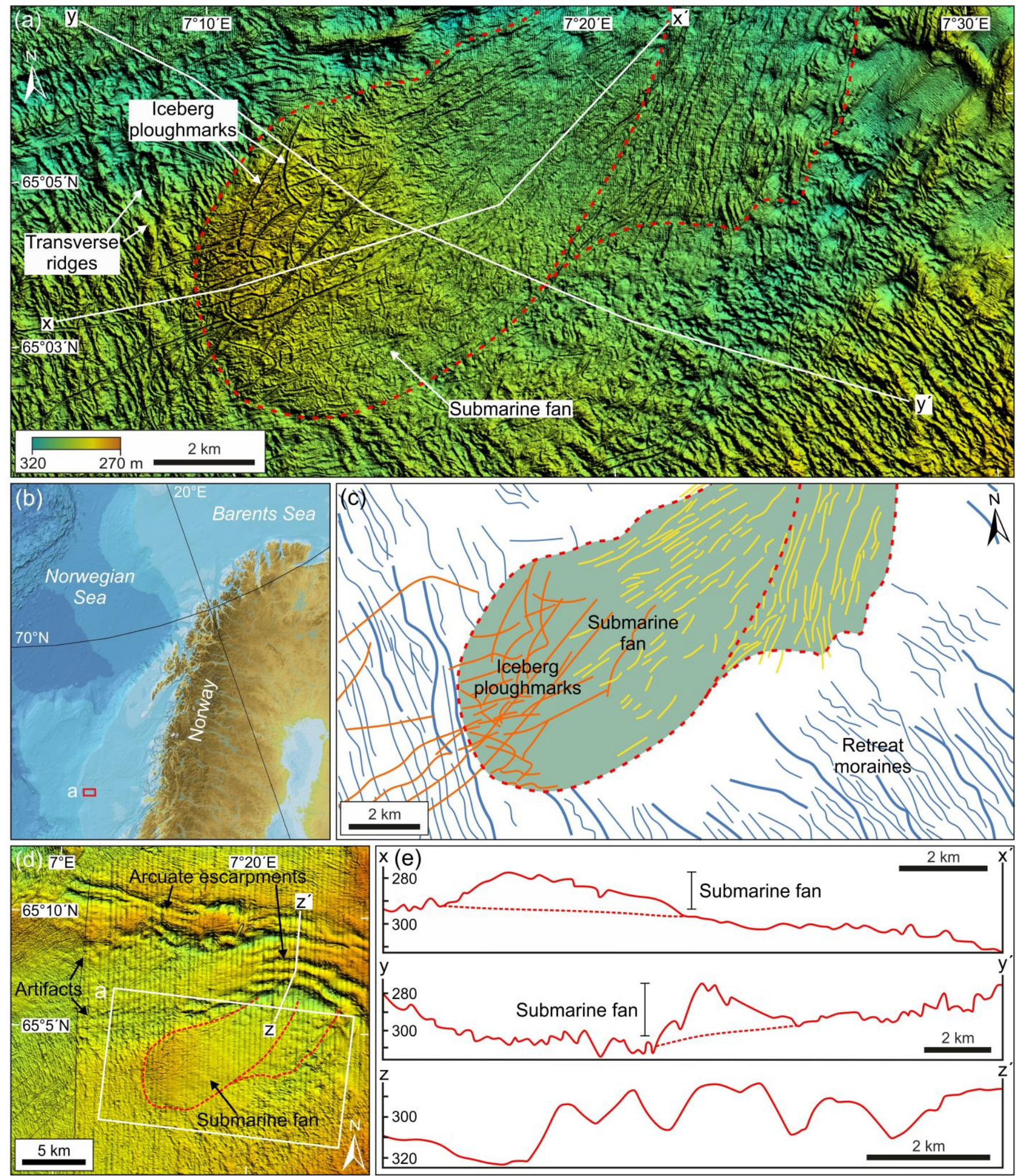

Fig. 1. (a) Seafloor morphology of a fan-like sedimentary depocentre and related landforms on Haltenbanken, mid-Norwegian shelf, based on high-resolution multibeam bathymetry. Acquisition system Kongsberg EM1000. Frequency $95 \mathrm{kHz}$. Grid-cell size 5 m. (b) Location of study area (red box; map from IBCAO v. 3.0). (c) Interpretation of morphological features in (a). Linear iceberg ploughmarks are coloured yellow and more chaotic ploughmarks in orange. Light and dark blue lines are smaller and relatively larger retreat moraines. (d) Regional seafloor morphology from the surface pick of 3D seismic data. Grid cell size $25 \mathrm{~m}$. (e) Bathymetric cross-profiles of the sedimentary depocentre and adjacent escarpments, located in (a) and (d). Dashed lines represent inferred base of depocentre. VE is x 50 for $\mathrm{x}-\mathrm{x}$ ', $\mathrm{x} 55$ for $\mathrm{y}-\mathrm{y}$, and $\mathrm{x} 33$ for $\mathrm{z}-\mathrm{z}$ '. The multibeam and 3D seismic imagery, and the geotechnical data, are courtesy of Statoil ASA. 